\title{
p53 protein in odontogenic cysts: Increased expression in some odontogenic keratocysts
}

G R Ogden, D M Chisholm, R A Kiddie, D P Lane

\begin{abstract}
Aims: To assess p53 protein expression in a range of odontogenic cysts arising in the mouth, including those of developmental and inflammatory origin.

Methods: p53 protein was identified using the polyclonal antibody $\mathrm{CM}-1$, together with a standard immunoperoxidase technique. A total of 36 cystic lesions were examined, all of which were histologically benign.

Results: Expression of p53 protein was identified within the lining of five of 12 odontogenic keratocysts but was not detected in the other cystic lesions in the series.

Conclusions: This is believed to be the first report that identifies increased expression of $p 53$ protein in benign cystic epithelium. The increased expression of p53 protein in the nucleus is usually associated with malignant disease. These findings are relevant to the management of odontogenic keratocysts which have a tendency to recur, and also to Gorlin Goltz syndrome in which keratocysts and multiple basal cell carcinomas are features.
\end{abstract}

(F Clin Pathol 1992;45:1007-1010)

p53 protein was first reported by Lane and Crawford in $1979 .^{1}$ It is a product of the p53 gene which is now classified as a tumour suppressor gene. ${ }^{23}$ The gene seems to be a frequent target for mutation, ${ }^{4}$ being seen as a common step in the pathogenesis of most human cancers. ${ }^{5}$ In normal cells p 53 protein has a very short half life, ${ }^{6}$ such that it cannot be detected immunohistochemically. ${ }^{7}$ Mutation of the p53 gene often results in increased stability of the gene product (p53 protein). ${ }^{8}$ Thus the mutant form can be detected using immunohistochemical techniques; numerous studies report that it has been identified in malignant cells but not in normal cells. . $^{9-12}$

We examined a range of oral mucosal lesions and only identified p53 expression in patients with oral cancer. ${ }^{13}$ However, cystic lesions affecting the oral cavity have not been previously examined for the presence of $\mathrm{p} 53$. The epithelial cells which comprise the lining of odontogenic cysts are derived from the primative oral epithelium of the oral mucosa and contribute to tooth formation. During and after this process such epithelia are a common source of cystic change within the jaw bones. This study examines three types of odonto- genic cysts: odontogenic keratocysts, dentigerous cysts, and radicular cysts. Histologically, the odontogenic keratocyst is characterised by an epithelial lining five to eight cells thick, with a prominent basal cell layer of columnar or cuboidal cells (fig 1). The keratinisation of the epithelium is predominantly parakeratotic, although sometimes orthokeratosis is seen. The cyst wall is usually thin unless inflammation is present. The surrounding connective tissue may contain islands of epithelium or separate small cysts. ${ }^{14-16}$ This cyst is of particular interest because of the reported high rate of mitotic activity within its lining, ${ }^{17}$ its tendency to recurrence, ${ }^{1418}$ and the association with Gorlin Goltz syndrome, ${ }^{19}$ in which multiple naevoid basal cell carcinomas may develop. It is important to note also that some odontogenic keratocyst linings show epithelial dysplasia and it is generally accepted that keratinising cysts have a greater tendency to malignant transformation than others. ${ }^{15}$ Dentigerous cysts are found near the crown of an unerupted tooth. Histologically, the cyst wall is composed of a thin layer of connective tissue lined by stratified squamous epithelium or by epithelium that is only two to three cells thick. The epithelium may include mucus producing cells and sometimes ciliated cells. In some cases the cyst lining is keratinised. ${ }^{16}$ Odontogenic kera-

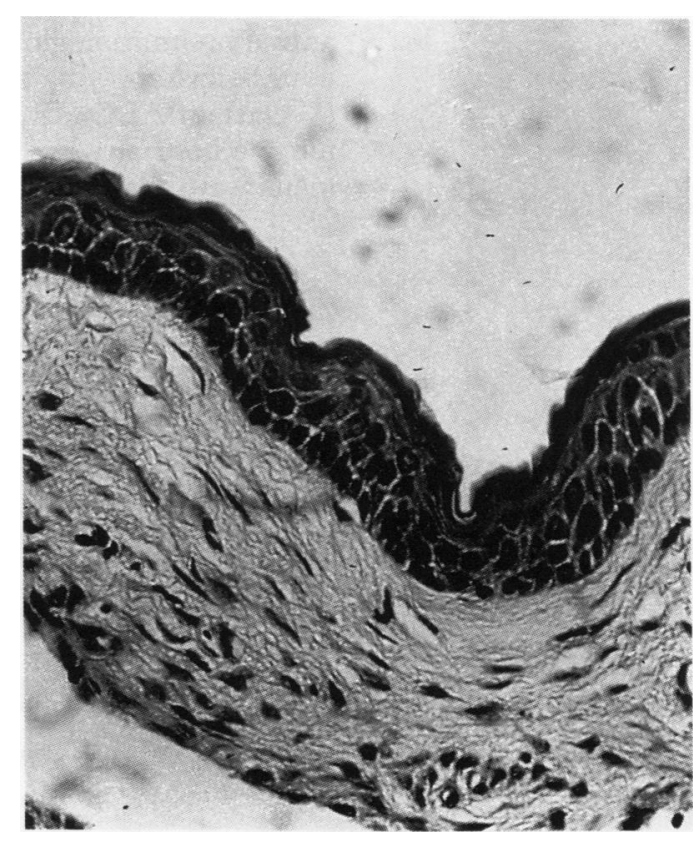

Figure 1 Classic histopathological features displayed by the odontogenic keratocyst obtained from case 4 (table 2) and illustrated in fig 2 and 3.

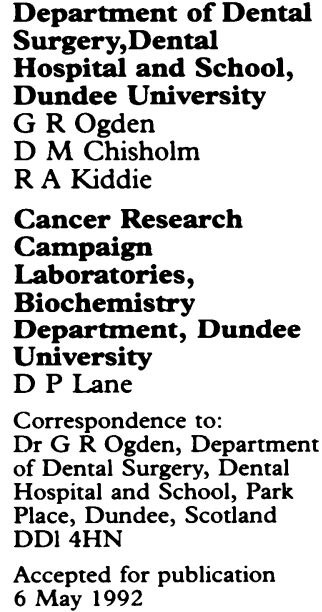


Table 1 Expression of p53 in cysts of the oral cavity

\begin{tabular}{llll}
\hline Cyst type & Examined & Positive & Negative \\
\hline Radicular cyst & 12 & 0 & 12 \\
Dentigerous cyst & 12 & 0 & 12 \\
Odontogenic keratocyst & 12 & 5 & 7 \\
\hline
\end{tabular}

tocyst and dentigerous cyst are both developmental cysts, but radicular cysts are inflammatory in origin. They arise as sequelae of dental caries from the effects of inflammation on epithelial residues situated in the apical portion of the periodontal ligament. They are the most common cysts found within the jaw, usually associated with a non-vital tooth. Histologically, most radicular cysts are lined by a non-keratinising stratified squamous epithelium. Other features include mucus metaplasia, hyaline bodies, cholesterol clefts with an associated foreign body giant cell reaction and an inflammatory cell infiltrate. ${ }^{16}$

\section{Methods}

This study was based on the examinations of 36 odontogenic cysts, all of which were routine surgical specimens fixed in $10 \%$ neutral buffered formalin. The cysts comprised 12 radicular cysts (three mandibular, nine maxillary), 12 dentigerous cysts (six each from the mandible and maxilla), and 12 odontogenic keratocysts (10 mandibular, two maxillary). For each specimen, sections were chosen randomly from paraffin wax embedded blocks which had been stained with haematoxylin and eosin p53 expression before. Four $5 \mu \mathrm{m}$ sections were cut from each block and dried overnight at $37^{\circ} \mathrm{C}$. The specimens were dewaxed and then washed in TRIS-buffered saline (TBS) and incubated overnight at $4^{\circ} \mathrm{C}$, with the polyclonal antibody CM-1 (diluted 1 in 1000 of $10 \%$ fetal calf serum in phosphate buffered saline (PBS)). CM-1 is a rabbit polyclonal antibody raised against the whole p 53 protein. ${ }^{20} \mathrm{~A}$ biotinylated antirabbit immunoglobulin was applied for one hour before applying the avidin:biotin complex (Vectastain ABC Kit, Vector Labs, England) for one hour at room temperature. The specimens were then incubated with a solution of diaminobenzidine and hydrogen peroxide in PBS for 10 minutes. A brown precipitate seen in the nucleus confirmed the presence of the p53 protein. The tissue specimens were not counterstained.

Two negative controls were used in each case. For one section a solution of $\mathrm{CM}-\mathrm{l}$ previously blocked with p53 protein was applied, whilst normal goat serum was applied to the second section.

Further staining of the odontogenic keratocysts was carried out using the monoclonal antibody PC10, which recognises the proliferating cell nuclear antigen (PCNA). This was used at a dilution of 1 in 250 . A biotinylated antimouse immunoglobulin was applied instead of the biotinylated antirabbit immunoglobulin used with CM-1.

To obtain an indication of the rate of cell division, the number of suprabasal mitoses was counted in a randomly selected area of 1500 epithelial cells in each specimen of odontogenic keratocyst, as described by Browne. ${ }^{4}$

\section{Results}

The results for p53 expression in a variety of oral cysts are given in tables 1 and 2 . None of the inflammatory radicular cysts nor developmental dentigerous cysts expressed p53. In each case the histopathological features were typical and unremarkable. The only cyst type in which p53 was detectable was the odontogenic keratocyst (fig 2) and a positive result was obtained in five of 12 . Staining with the PCNA antibody (PC10) indicated that the p53 positive cells were actively dividing, because similar regions were positive for both antibodies (fig 3). CM-1 positivity was identified in most of the basal cells; staining with PC10 was much more intense, being present in all basal cells and most parabasal cells. All odontogenic keratocysts were positive for PCNA. Two of the five cases positive for p53 were recurrent lesions compared with five of the seven p53 negative keratocysts. One female patient had features associated with the Gorlin Goltz syndrome (table 2), namely hypertelorism, spina bifida, and odontogenic keratocysts. However, to date, no basal cell neoplasms have

Table 2 Characteristics of the odontogenic keratocysts assessed for p53 expression

\begin{tabular}{|c|c|c|c|c|c|c|c|}
\hline \multirow{2}{*}{$\begin{array}{l}\text { Cyst } \\
\text { No }\end{array}$} & \multicolumn{2}{|c|}{ Patient } & \multirow[b]{2}{*}{ Site } & \multirow{2}{*}{$\begin{array}{l}\text { Multiple } \\
\text { cysts }\end{array}$} & \multirow{2}{*}{$\begin{array}{l}\text { Recurrent } \\
\text { cysts }\end{array}$} & \multirow[b]{2}{*}{ Histopathological features } & \multirow{2}{*}{$\begin{array}{l}\text { p53 } \\
\text { expression }\end{array}$} \\
\hline & Age & Sex & & & & & \\
\hline 1 & 24 & $\mathbf{F}$ & L maxilla (molar) & + & - & $\begin{array}{l}\text { Moderate focal inflammation } \\
\text { mild epithelial hyperplasia }\end{array}$ & + \\
\hline 2 & 14 & $\mathbf{F}$ & L mandible (molar) & - & - & Mild focal inflammation & + \\
\hline 3 & 16 & $\mathbf{F}$ & L maxilla (premolar) & - & - & Mild epithelial hyperplasia & + \\
\hline 4 & 75 & $\mathbf{M}$ & I mandible (ramus) & + & + & Mild diffuse inflammation & + \\
\hline 5 & 48 & $\mathbf{F}$ & L mandible (body) & - & - & Mild focal inflammation & + \\
\hline 6 & 21 & $\mathbf{F}$ & L mandible (molar) & + & - & $\begin{array}{l}\text { Moderate focal inflammation } \\
\text { Mild epithelial hyperplasia } \\
\text { Satellite cysts (Types } 1 \text { and 2) }\end{array}$ & - \\
\hline 7 & 45 & $\mathbf{F}$ & L mandible (ramus) & + & - & Satellite cyst (Type 1 ) & - \\
\hline 8 & 59 & $\mathbf{F}$ & $\mathbf{R}$ mandible (ramus) & - & - & $\begin{array}{l}\text { Mild focal inflammation } \\
\text { Cholesterol, hyaline }\end{array}$ & - \\
\hline 9 & 16 & $\mathbf{M}$ & L mandible (ramus) & - & - & Mild focal inflammation & - \\
\hline 10 & 35 & $\mathbf{M}$ & $\mathbf{R}$ mandible (ramus) & + & - & $\begin{array}{l}\text { Mild diffuse inflammation } \\
\text { Cholesterol, hyaline }\end{array}$ & - \\
\hline 11 & 75 & $\mathbf{M}$ & L mandible (angle) & + & + & Mild focal inflammation & - \\
\hline 12 & 63 & $\mathbf{F}$ & L mandible (premolar) & + & + & $\begin{array}{l}\text { Mild diffuse inflammation } \\
\text { Satellite cysts (Types } 1 \text { and } 3 \text { ) }\end{array}$ & - \\
\hline
\end{tabular}


Figure 2. Identification of p53 positive cells using CM-1 in most basal cells in the lining of a recurrent odontogenic keratocyst (case 4).

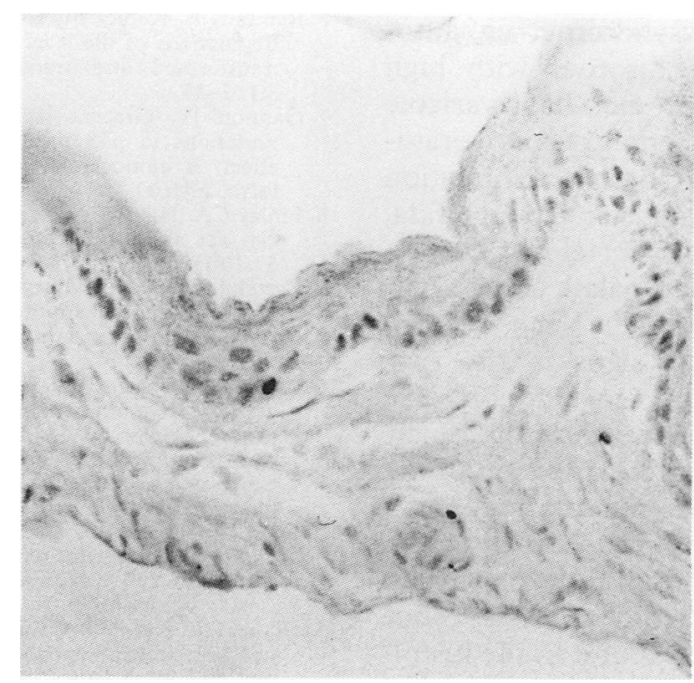

presented in this case. Of the two cysts examined from this patient with Gorlin Goltz syndrome, the first, removed from the mandibular molar region, proved $\mathrm{p} 53$ positive. The other cyst, removed three years later from the molar region of the maxilla, was p53 negative.

Two cysts from the same elderly male patient, removed at one operation also behaved differently. The first, removed from the angle of the mandible, was p53 negative; the second, removed from the ramus of the mandible, on the same side as the first, was p53 positive. Three of the 12 cysts were recurrent, and of these one was p53 positive. A history of multiple cysts of the jaws was given by two of five patients with cysts showing p53 expression. This history was noted in five of seven patients with cysts that did not express p53.

By definition, all odontogenic keratocysts reported in this paper had typical histopathological features. A striking feature was the remarkable consistency of the histopathological appearance by the epithelium. All cyst capsules showed mild to moderate non-specific chronic inflammatory cell infiltration. Of the seven odontogenic keratocysts in which p53 expression was absent, six capsules or linings contained either cholesterol clefts, hyaline bodies, or satellite cysts. The latter feature

Figure 3 Identification of PCNA using PC10 in the basal and parabasal cells of the $p 53$ positive recurrent odontogenic keratocyst illustrated in fig 2.

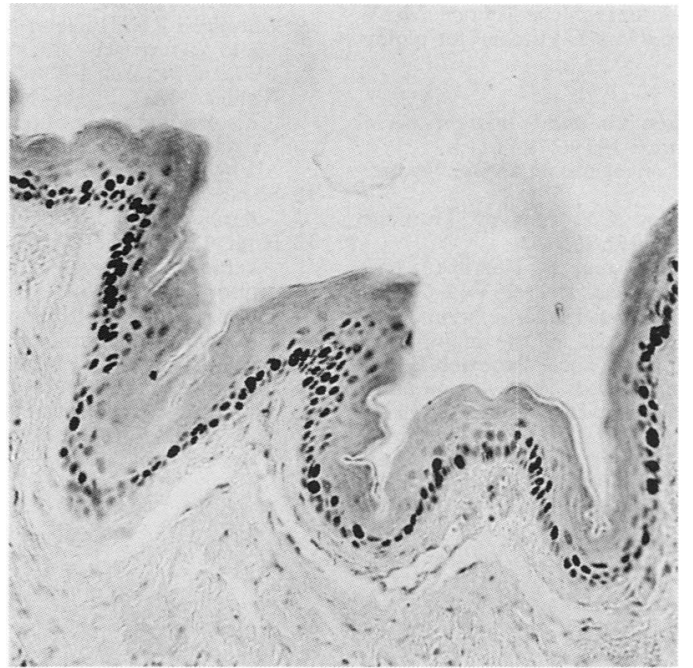

comprises three types ${ }^{14}$ and each, in turn, represents a proliferative, mature, or degenerative phase in the life cycle of the cyst. Interestingly, the five linings which were p53 positive lacked the presence of cholesterol, hyaline, and satellite cysts in the sections examined. However, a larger series will be necessary before a firm conclusion with regard to the clinical relevance of this finding can be drawn. The number of suprabasal mitotic figures per 1500 cells varied from 0 to 4 but no difference could be made between the groups p53 positive and p53 negative linings.

Thus the two groups of odontogenic keratocysts could not be distinguished in terms either of patient medical or dental history, including age and sex, nor recurrence or mitotic activity of the cyst lining.

\section{Discussion}

Many papers have recently reported the association of $\mathrm{p} 53$ protein with a variety of different malignant tumours. ${ }^{3-5}$ However, it is important to emphasise that the CM1 antibody recognises both wild and mutant forms of p53. Thus identification of p53 in the lining of some odontogenic keratocysts should not necessarily imply an association with malignant disease. It is known that the cellular environment can affect the stability of p53. ${ }^{\circ}$ For example, the enzymatic pathways for p53 degradation may be inactivated. ${ }^{21}$ Certain viruses, such as adenovirus, can also stabilise p53 in non-malignant tissue. ${ }^{22}$ Furthermore, because $\mathrm{CM} 1$ recognises the whole p53 protein it is more likely to detect its presence than monoclonal antibodies that are directed against specific epitopes of the p53 protein. CM1 seems to produce a much stronger "signal" than some of the earlier p53 monoclonal antibodies. ${ }^{21}$ Hence it seems to be more sensitive. Certainly the staining seen in odontogenic keratocysts is much weaker than that seen in oral cancers. ${ }^{13}$ Various factors peculiar to the keratocyst may help to explain the occurrence of p53 positivity. Firstly, the cyst has a tendency to recur, suggesting increased epithelial activity. ${ }^{14}$ Although the rate of recurrence may depend more on the method of treatment, ${ }^{23}$ recurrence up to $60 \%$ has been reported. ${ }^{15}$ This may in part be due to its high mitotic rate. Main found an average of eight mitoses for every $1 \mathrm{~cm}$ of lining examined (range 0-22), which was much higher than the other cysts he examined $^{17}$ (although Browne ${ }^{14}$ calculated a rate of 3.9 in his study of 130 primary and nine recurrent keratocysts). The position of these mitoses may also be influential. The number of mitoses situated in the basal region of oral epithelium from various sites has been estimated to be between $30-50 \% .^{24-26}$ However, only $10 \%$ were found in the basal region of odontogenic keratocysts as reported by Browne $^{14}$ and the present study supports this view. If PCNA positivity can be related to cell proliferation, ${ }^{27}$ then our results would support the finding of increased nuclear activity.

The other factor of possible importance is the association between odontogenic kerato- 
cysts and Gorlin Goltz syndrome, an autosomal dominant genetic disorder with high penetrance. $^{28}$ The syndrome has variable expression, and includes odontogenic keratocysts, basal cell naevi/carcinomas, bifurcation of the ribs, rib or vertebral fusion, spina bifida, intracranial calcification, hypertelorism, mental retardation, cleft lip and palate and palmar and plantor pitting. ${ }^{1929}$ The lack of consistency of these physical signs in the syndrome 18 1929 would tend to support the opinion of Browne ${ }^{14}$ that the occurrence of jaw cysts represents the minimal expression of the syndrome. However, this remark may have been based on his finding of no difference in the histology of single, multiple, or Gorlin Goltz syndrome associated keratocysts. Since then differences have been found in the histology of odontogenic keratocysts that presented as single cysts compared with those in the Gorlin Goltz syndrome, ${ }^{30}$ principally an increase in mitotic activity in the lining of cysts from the Gorlin Goltz syndrome.

p53 expression may therefore be a marker for the syrdrome particularly as p53 expression has previously been associated with malignancy, and the syndrome is associated with development of basal cell carcinomas. However, not all cysts removed from our one case of Gorlin Goltz syndrome were p53 positive. One possibility is that $\mathrm{p} 53$ positivity may be indicative of potential malignant change within the cyst lining. Malignant transformation in jaw cysts, although rare, is thought to occur more frequently in keratinising cysts ${ }^{163031}$ and has been reported in odontogenic keratocysts ${ }^{32} 33$ A more extensive study of keratocysts from Gorlin Goltz syndrome and, in particular, those cases associated with basal cell neoplasms is now required: particularly as other tumours may be associated with the Gorlin Goltz syndrome. ${ }^{34}$ It has been suggested that there might be a hereditory embryological maldevelopment in these patients which predisposes them to further cysts and recurrences. It may be important, then, that of the odontogenic cysts examined in this study, only odontogenic keratocysts expressed p53 positive cells, a cyst whose characteristics have been compared with that of an aggressive tumour. $^{34}$

We thank Mr G Carmichael for photographic assistance, Mrs V Wilson for technical assistance, and Mrs E Mitchell for typing the manuscript.

1 Lane DP, Crawford LV.T-antigen is bound to host protein in SV40-transformed cells. Nature 1979;278:261-3.

2 Lane DP, Benchimol S. p53: oncogene or anti-oncogene? Genes Develop 1990;4:1-8.

3 Levine AJ, Momand J, Finlay CA. The p53 tumour suppressor gene. Nature 1991;351:453-6.

4 Hollstein M, Sidransky D, Vogelstein B, Harris C. p53 mutations in human cancer. Science 1991:253:49-53.

5 Lane DP. Mutation of the p 53 gene and accumulation of the p53 protein: Common steps found in the majority of human cancers. General Motors Cancer Research Foundation. In: Fortner JC, Rhodes JE, eds. Accomplishments in cancer research 1990. Philadelphia: JP Lippincott, 1991: cancer 22.65.
6 Reihsaus E, Kohler M, Kraiss S, Oren M, Montenarh M. Regulations of the level of the oncoprotein p53 in nontransformed and transformed cells. Oncogene 1990 5:137-45.

7 Gannon JV, Greaves R, Iggo R, Lane DP. Activating mutations in $\mathrm{p} 53$ produce a common conformational effect. A monoclonal antibody specific for the mutant form. EMBO f 1990;9:1595-602.

8 Finlay CA, Hinds PW, Levine AJ. The p53 proto-oncogene can act as a suppressor of transformation. Cell 1989; 57:1083-93.

9 Bartek J, Bartkova J, Voitesek B, et al. Patterns of expression of the p 53 tumour suppressor in human breast tissues and tumours in situ and in vitro. Int $\Im$ Cancer 1990; 46:839-44.

10 Chiba I, Takahashi T, Nau MM, et al. Mutations in the p53 gene are frequent in primary resected non-small cell lung caner. Oncogene 1990:5:1603-10.

11 Iggo R, Gatter K, Bartek J, Lane DP, Harris AL. Increased expression of mutant forms of p53 oncogene in primary lung cancer. Lancet 1990;335:675-9.

12 Field JK, Spandidos DA, Malliri A, et al. Elevated p53 expression correlates with a history of heavy smoking in squamous cell carcinoma of the head and neck. $\mathrm{Br}$ Cancer 1991;64:573-7.

13 Ogden GR, Kiddie RA, Lunny DP, Lane DP. Assessment of p 53 protein expression in normal, benign and malignant p53 protein expression in normal, benig

14 Browne RM. The odontogenic ker atocyst histological features and their correlation with clinical behaviour. $\mathrm{Br}$ Deatures and their correla $1971 ; 131: 249-59$.

15 Toller PA. Origin and growth of cysts of the jaws. Ann R Coll Surg Engl 1967;40:306-36.

16 Pindborg JJ, Kramer IRH. Histological typing of odontogenic tumours, jaw cysts and allied lesions. International histological classification of tumours No 5. Geneva: World Health Organisation, 1971:39-42.

17 Main DMG. The enlargement of epithelial jaw cysts. Odontologisk Revy 1970;21:29-49.

18 Pritchard LJ, Delfino J, Ivey DM, Sclaroff A, Giglio JA. Variable expressivity of the multiple nevoid basal cell carcinoma syndrome. $f$ Oral Maxillofac Surg 1982;40: 261-9.

19 Gorlin RJ, Pindborg JJ. Multiple basal cell nevi odontogenic cysts and skeletal abnormalities. In: Syndromes of the head and neck.

20 Midgley CA, Fisher CJ, Bartek J, Vojtesek B, Lane DP, Barnes DM. Analysis of p53 expression in human tumours: an antibody raised against human p53 expressed in E-coli. $\mathcal{F}$ Cell Sci 1992;101:183-9.

21 Bennett WP, Hollstein MC, He A, et al. Archival analysis of p53 genetic and protein alterations in Chinese esophageal cancer. Oncogene 1991;6:1779-84.

22 van den Heuvel SJL, van Laar T, Kast WM, Melief CJM, Zantema A, van der Eb AJ. Association between the cellular p53 and the adenovirus 5 E1B-55kd proteins reduces the oncogenicity of Ad-transformed cells. EMBO reduces the oncogeni

23 Bramley PA. Treatment of cysts of the jaws. Proc $R$ Soc Med $1971 ; 64 ; 547-50$.

24 Meyer J, Marwah AS, Weinmann JP. Mitotic rate of gingival epithelium in two age groups. $\mathcal{f}$ Invest Dermatol 1956;27:237-47.

25 Gargiulo AW, Wentz FM, Orban B. Mitotic activity of human oral epithelium exposed to $30 \%$ hydrogen peroxide. Oral Surg 1961;14:474-92.

26 Hayes RL, Silberkweit M, Soni NN, Simpson TH. Pattern of mitotic activity and cell densities in normal gingival epithelium of children. 7 Dent Res 1964;43:217-23.

27 Hall PA, Levison DA, Woods AL, et al. Proliferating cell nuclear antigen (PCNA) immunolocalization in paraffin sections: an index of cell proliferation with evidence of sectionst an index 1990;162:285-94.

28 Rogerson KC. Gorlin's Syndrome: An update on diagnosis and management. Oral Maxillofac Surg Clin North Am and management.

29 Gundlach KKH, Kiehn M. Multiple basal cell carcinomas and keratocysts - the Gorlin and Goltz syndrome. I Maxillofac Surg 1979;7:299-307.

30 Woolgar JA, Rippin JW, Browne RM. A comparative histological study of odontogenic keratocysts in basal cell naevus syndrome and control patients. $f$ Oral Pathol 1987;16:75-80.

31 Shear M. Primordial cyst (keratocyst). In: Cysts of the oral regions. 2nd Ed. Bristol: PSG Wright. 1983:29.

32 High AS, Quirke P, Hume WJ. DNA-ploidy studies in a keratocyst undergoing subsequent malignant transformation. F Oral Pathol 1987;16:135-8.

33 Moos KF, Rennie JS. Squamous cell carcinoma arising in a mandibular keratocyst in a patient with Gorlin's synmandibular keratocyst in a patient with Gorlin's
drome. Br f Oral Maxillofac Surg 1987;25:280-4.

34 Partridge M, Towers JF. The primordial cyst (odontogenic keratocyst): its tumour-like characteristics and behaviour. keratocyst): its tumour-like characteristics
Br f Oral Maxillofac Surg 1987;25:271-9. 